\title{
Sustainable Manufacturing Practices and Sustainability Performance: A Conceptual Framework for Manufacturing SMEs
}

\author{
WEI QI LIM \\ Putra Business School, Level 3, Office Building of the Deputy Vice Chancellor \\ (Research \& Innovation) UPM, 43400 Seri Kembangan, Selangor \\ E-mail: weiqi1108@hotmail.com \\ DEVIKA NADARAJAH (Corresponding author) \\ Putra Business School, Level 3, Office Building of the Deputy Vice Chancellor \\ (Research \& Innovation) UPM, 43400 Seri Kembangan, Selangor \\ E-mail: devika@putrabs.edu.my
}

\section{SAZALI ABD WAHAB}

Putra Business School, Level 3, Office Building of the Deputy Vice Chancellor (Research \& Innovation) UPM, 43400 Seri Kembangan, Selangor E-mail: sazali@putrabs.edu.my

Received: January 28, 2021 Accepted: February 26, $2021 \quad$ Published: March 2, 2021 doi:10.5296/bms.v12i1.18253ＵRL: https://doi.org/10.5296/bms. v12i1.18253

\begin{abstract}
In the Sustainable Development Goals Summit in September 2019, world leaders addressed current and future sustainability challenges faced by the world, including poverty, inequality, climate change, environmental degradation, peace, and justice. However, the Covid-19 pandemic has shocked and dampened global sustainable development efforts. Malaysian manufacturing small and medium enterprises (SMEs) are not exempt from this tragedy, as
\end{abstract}


they have suffered economically, socially, and environmentally. The goal of this paper is to establish sustainable manufacturing practices (SMPs) as a dynamic internal strategic action for manufacturing firms that transforms firm capabilities into sustainability performance. The authors conducted an extensive literature search to explore global sustainability issues and narrowed the scope to issues encountered by Malaysian manufacturing firms. The most commonly used terminologies of sustainability, sustainable practices, and sustainability performance were subsequently analyzed to conceptually develop a holistic framework for future studies. Specifically, the authors proposed an explanatory quantitative study to comprehend the link between firm capabilities and multidimensional sustainability performance with the integration of SMPs as a mediator. The results of the analysis would provide useful recommendations for the manufacturing sector and directions for future studies. Additionally, this paper enriches the theory of the Dynamic Capability View by bringing in the sustainability model to explain the development process of sustainability performance among Malaysian manufacturing SMEs. This article does not just inform firms and authorities on the importance of SMPs for superior performance but also guides firms towards understanding and improving their current SMPs. Managers in the manufacturing sector would benefit from this paper by learning and implementing effective sustainable strategies in their operations management to improve sustainability-related outcomes.

Keywords: sustainable manufacturing practices, sustainability performance, firm capabilities, manufacturing SMEs, Covid-19

\section{Introduction}

In the Sustainable Development Goals Summit in September 2019, world leaders addressed current and future sustainability challenges faced by the world, including poverty, inequality, climate change, environmental degradation, peace, and justice (The United Nations, 2020). Worldwide, stakeholders have been urged to review sustainability issues from societal, economic, and environmental perspectives to develop holistic strategies to improve earlier deprivations (Salwa et al., 2017). Global partnership is thus required to jointly reduce global poverty, enhance health and education, minimize inequalities, drive economic growth, mitigate climate change, and safeguard natural resources.

The year 2020 was both tough and challenging, with the Covid-19 pandemic dampening global sustainable development efforts and affecting all economic sectors, organizations, and small and medium enterprises (SMEs). Due to the prolonged lockdown measures implemented worldwide, millions of enterprises in the hardest-hit sectors currently suffer from the high risks of winding down while countries struggle to manage an increased unemployment rate (The United Nations, 2020). Figure 1 demonstrates global working hours in the second quarter of 2020, which were estimated at $10.5 \%$ lower than the pre-Covid-19 period, equaling the loss of almost 305 million full-time jobs (International Labor Organization, 2020). 


\section{Macrothink}

\begin{tabular}{|c|c|c|}
\hline & 1st quarter 2020 & 2 nd quarter 2020 \\
\hline \multirow{2}{*}{ World } & 4.5 & \\
\hline & 1st quarter 2020 & 2nd quarter 2020 \\
\hline Low-income countries & 1.6 & 8.8 \\
\hline Lower-middle income countries & 1.9 & 12.5 \\
\hline Upper-middle income countries & 8.6 & 8.7 \\
\hline \multirow[t]{2}{*}{ High-income countries } & 1.6 & 11.6 \\
\hline & 1st quarter 2020 & 2 nd quarter 2020 \\
\hline Africa & 1.6 & 9.6 \\
\hline Americas & 1.3 & 12.4 \\
\hline Arab States & 1.8 & 10.3 \\
\hline Asia and the Pacific & 6.5 & 10.0 \\
\hline Europe and Central Asia & $\overline{1.9}$ & 11.8 \\
\hline
\end{tabular}

Figure 1. Estimated drop in aggregate working hours, globally and by region

Inequalities related to income, forced labor, and human rights have always existed in regions across the world. Vulnerable communities suffer under a poor health management system while natives, refugees, and migrants survive in an atmosphere rife with discrimination and hatred (The United Nations, 2020). Furthermore, as a consequence of urbanization and industrialization, the world is experiencing climate change, global warming issues, and a deficiency of fossil fuel sources. As illustrated in Figure 2, climate change, represented by the global mean temperature difference, has reached new peaks in the past five years; this trend is forecasted to continue until the year 2025 (The United Nations, 2020).

\section{Global mean temperature difference from 1850-1900 ( $\left.{ }^{\circ} \mathrm{C}\right)$}

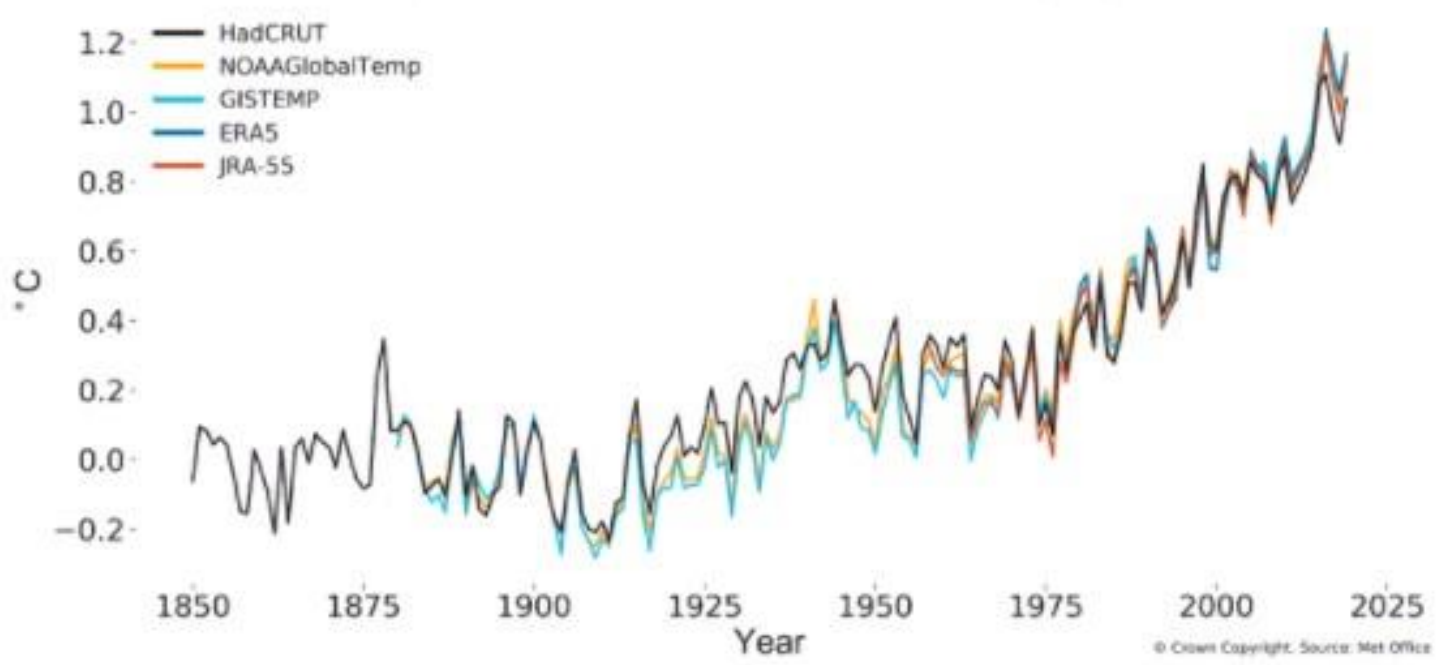

Figure 2. Global mean temperature difference from 1850 to 2020 and its forecast in 2025

Sustainability issues occurring worldwide have triggered concerns from stakeholders, socialists, and environmentalists. In Malaysia, studies show that the current progress of sustainable initiatives is limited to the "6R approach", with firms generally unprepared to 
thoroughly consolidate sustainability requirements when dealing with externally focused sustainable manufacturing practices (SMPs) (Hami et al., 2019; Shakeel et al., 2019). However, sustainable strategic actions are necessary to form the basis of nations' and businesses' sustainability, dynamism, and competitiveness in the long run. Research evidence also suggests that firm performance is heavily dependent on its ability to generate strategic actions that address sustainability concerns (Liboni et al., 2016). As such, the objective of this paper is to establish SMPs as a dynamic internal strategic action for manufacturing SMEs that transforms firm capabilities into multidimensional sustainability performance, namely environmental, economic, and social performance. SMPs support sustainable development goals (Goal 11: Sustainability), under which the United Nations intends to make cities inclusive, safe, resilient, and sustainable (The United Nations, 2020). Towards this end, the implementation of sustainable initiatives would support local governments and firms by contributing knowledge for informed decisions, mitigating economic impacts, initiating recovery, and ultimately, providing sustainable solutions for a cleaner and healthier community.

The Covid-19 outbreak has seriously hampered the sustainable development of Malaysian manufacturing SMEs, leaving manufacturers struggling to figure out sustainable strategic actions and survival strategies for business continuity. In the wake of the virus outbreak, SME manufacturers have adopted flexible business strategies to strengthen their financial position and search for new resources and opportunities to develop new business lines, products, and offerings (Syed, 2019). In fact, firms are currently embracing innovative marketing platforms and online channels to cater to the change in consumer purchasing behaviors (Marketing Insight, 2020). Moving forward, manufacturers are also required to adopt Industrial 4.0 approaches to minimize dependency on the unskilled foreign workforce (Che Omar et al., 2020). Taking these changes into consideration, it is essential to ascertain how some firms leverage their capabilities via strategic actions in support of sustainability while others do not. In firms that do not apply strategic actions, it is important to explore the alternate initiatives and practices that help them mediate sustainability issues (Rashid et al., 2015). However, thus far, the extant literature has lacked an explanatory model that provides decision-making solutions to manufacturing SMEs encountering sustainability issues. Researchers have instead focused on the individual relationships among firm capabilities, practices, and firm performance, largely neglecting to integrate all relevant variables in a complete framework. Moreover, though earlier studies have demonstrated the direct relationship between firm capabilities and performance, limited research has concurrently examined the interrelationships between firm capabilities, SMPs, and sustainability performance, especially in the context of manufacturing SMEs. Considering that firms are dealing with unexpected sustainability issues, Hahn et al. (2015) suggested that firms look into the sustainability paradigm to adapt to changes in the business environment.

To address these issues, we critically analyze extant the research and terminologies pertaining to sustainability, sustainable development, and sustainability performance, with the aim to conceptually develop a holistic framework for future studies. Particularly, this paper attempts 
to answer the following research questions: (1) What is the relationship between firm capabilities and sustainability performance? and (2) What is the relationship between firm capabilities and sustainability performance when mediated by SMPs? Guided by these questions, our thought process and resulting research questions are visualized in Figure 3. This study is both timely and important in enriching the Dynamic Capability View (DCV) by bringing in the sustainability model to explain the development of sustainability performance in the Malaysian manufacturing sector. This article will not just inform firms and authorities on the importance of SMPs for superior performance but will also guide firms towards understanding and improving their current implementation strategies. This paper also aids managers from the manufacturing sector in introducing effective sustainable strategies in their firms' operations management to improve sustainability-related outcomes.

\begin{tabular}{|c|}
\hline $\begin{array}{c}\text { What are the common terminologies of sustainable practices and capabilities in the } \\
\text { literature? }\end{array}$ \\
\hline$\frac{1}{t}$ \\
\hline $\begin{array}{l}\text { Perform a literature review in ScienceDirect and Research Gate using the key words } \\
\text { 'ecological', 'environmental', 'green', 'lean', 'natural', 'sustainable', and 'eco' }\end{array}$ \\
\hline$\nabla$ \\
\hline $\begin{array}{l}\text { Rank sustainable practices and capabilities according to their frequency and } \\
\text { commonalities. }\end{array}$ \\
\hline 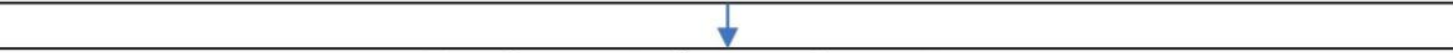 \\
\hline $\begin{array}{l}\text { Development of research questions: } \\
\text { 1. What is the relationship between firm capabilities and sustainability } \\
\text { performance? } \\
\text { 2. What is the relationship between firm capabilities and sustainability performance } \\
\text { when mediated by Sustainable Manufacturing Practices (SMPs)? }\end{array}$ \\
\hline 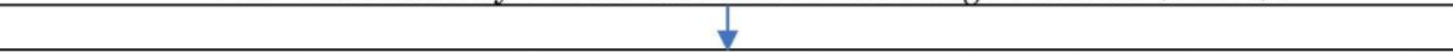 \\
\hline $\begin{array}{r}\text { Quantitative studies proposed to verify } \\
\text { Malaysian ma }\end{array}$ \\
\hline
\end{tabular}

Figure 3. Development of research questions

\section{Literature Review}

\subsection{Background of Study}

SMEs can be defined as firms with a sales turnover not exceeding RM50 million or employment not exceeding 200 workers. In Malaysia, SMEs comprise $98.5 \%$ of total business establishments (SMECorp, 2019), meaning that any business or economic turmoil will unavoidably impact various SME sectors and national economic progress (Svatošová, 2019). SMEs are thus the backbone of the economy and the second largest sector contributing to national gross domestic product (GDP) growth after the services sector. In particular, the manufacturing SME segment contributed $34.6 \%$ to Malaysian GDP and $46.7 \%$ to employment in the year 2019 (Department of Statistics Malaysia, 2020). The manufacturing sector itself, in 2019, contributed RM 316 billion (22.3\%) to Malaysia's GDP of RM 1.4 trillion, evidencing its significant role in the development of the Malaysian economy. 


\section{Ml Macrothink}

Recent research in Malaysia demonstrated that manufacturing activities have caused the depletion of natural resources, overutilization of energy, and generation of significant amounts of municipal solid waste. The current waste management system in Malaysia is incapable of digesting the huge disposal rate of municipal solid waste due to the infancy of its incineration process. Thus, the disposal of unwanted waste substances has led to hazardous sustainability issues, including environmental pollution, public and worker health damage, economic growth stagnation, and production competence loss (Chua \& Bashir, 2019). Moreover, in the past, the treatment of foreign workers in the industry, non-compliance to social practices, and forced labor have always been topics of controversy raised by stakeholders, implying that manufacturers face difficulties achieving social goals (Kumar, 2019). The Covid-19 pandemic crisis has only exacerbated these issues, as Malaysia has suffered economically, socially, and environmentally from its effects. The series of movement control orders entailed supply chain interruptions, business closures, and hiring freezes. As illustrated in Figure 4, GDP recorded a sharp plunge of $-17.1 \%$ and $-2.7 \%$ in the second and third quarters of 2020, respectively, with an estimated economic loss of RM67 billion (Bank Negara Malaysia, 2020).

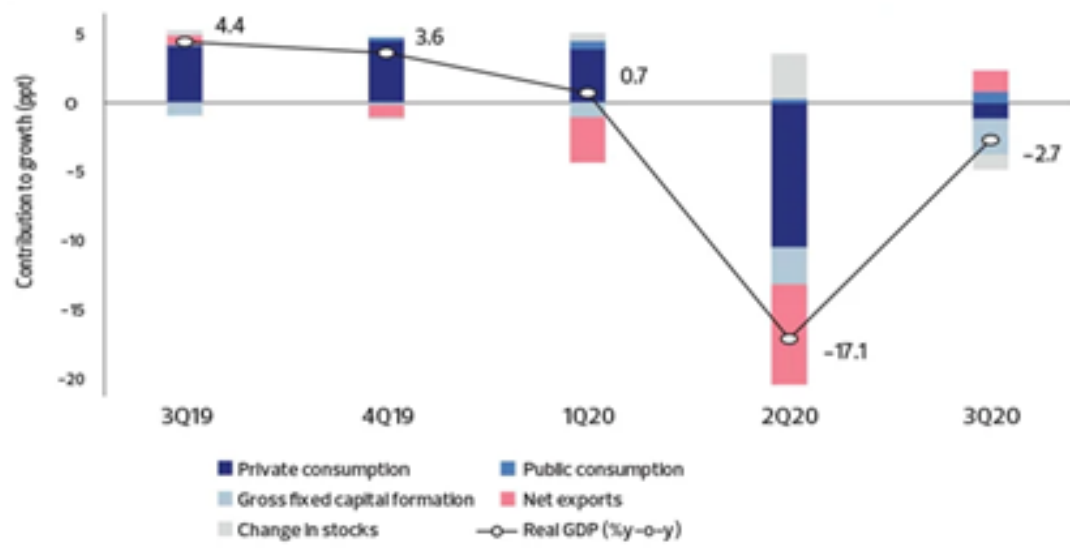

Figure 4. Real gross domestic product growth (\%) in Malaysia from Q3 2019 to Q3 2020

The recent resurgence of the pandemic has further worsened domestic sentiments and economic activities. Workplace Covid-19 clusters among migrant workers worried communities as the virus outbreak possibly spread across manufacturing sectors, such as electrical and electronics, chemical industry, and food and beverage. This exerted severe consequences on the Industrial Production Index due to the closure of factory operations to screen workers and sanitize facilities. Thus far, manufacturers impacted by Covid-19 include Ipoh-based electronics manufacturer Salutica Bhd, Senawang-based glove maker Careplus Group Bhd, Top Glove Corporation, and automotive leather seat manufacturer Pecca Group Bhd (Surendran, 2020). The virus outbreak in these manufacturers' premises triggered the authorities to conduct surprise spot checks at several foreign workers' hostels. It was then revealed that some companies had been breaching the law as the accommodation areas were found to be overcrowded, poorly ventilated, and insufficiently sanitized (The Star, 2020). Such incompliance of social practices could lead to major impacts on the industry, including 
the ceasing of operations, heavy fines, ruined brand image, and threats to business survival.

Overall, sustainability issues persist in Malaysia, made worse by the Covid-19 outbreak that has hindered sustainable development. Despite the proven importance of sustainable management systems, the enforcement of regulations on environmental and social protection remains rather poor. Thus, firms should prioritize their focus on natural environment conservation, sustainable end-of-life management, and sustainable practices. It is time for Malaysian firms to revamp, transform, and adapt to a more sustainable business model that utilizes natural resources wisely so as to accomplish social, economic, and environmental sustainability while ensuring manufactured products are safe for societies and end users.

\subsection{Evolution of Sustainable Development and Sustainability}

To resolve the issues of limited resources and environmental degradation, firms have been urged to move towards sustainability. The concept of sustainability is proposed to strike a balance between the utilization and restoration of resources within firms. In other words, firms' aim to both restore resources that are being consumed today and generate resources for the future is considered as a sustainable approach that directs firms towards sustainable development. To better understand this phenomenon, it is important to first differentiate between "sustainable development" and "sustainability".

The term "sustainable development" was first introduced by the United Nations in 1987 as "development that meets the needs of the present without compromising the ability of future generations to meet their needs." This concept did not progress much initially as most firms lacked exposure on how to inculcate environmental awareness into their business structure. Meanwhile, there has been no common definition of "sustainability" thus far. Debates about the definition of sustainability range from philosophical viewpoints to multidimensional explanations; nevertheless, the main concern of various definitions has always been the influence of current decisions on upcoming generations (Iranmanesh et al., 2016). A number of scholars defined sustainability by focusing on dimensions related to the triple bottom line. For example, Elkington (1997) recommended sustainability as "an extension of the organizational perspective, in consideration of equalizing economic, environmental, and social aspects of sustainability." Meanwhile, the Oxford Dictionary described sustainability as "the avoidance of the depletion of natural resources in order to maintain an ecological balance." Therefore, the concepts of "sustainable development" and "sustainability" cannot be used interchangeably as they comprise unique qualitative factors.

Scholars have generally considered sustainability and sustainable development as two distinct yet critical concepts that create a platform for discussion. Although both concepts are interrelated, differences do exist between them. As far as sustainable development is concerned, the ethical standard of achieving equity between present and future generations is the priority. This consists of economic and social development that safeguards environmental, societal, and human well-being. In simpler terms, sustainable development refers to the process of implementing sustainable practices that are environmentally sound, economically 
healthy, and societally just in an industry. On the other hand, sustainability refers to the goal or endpoint of sustainable development. Hence, a firm that has undergone the sustainable development process is a firm that has reached sustainability.

The notion of sustainable development in manufacturing was developed in the $20^{\text {th }}$ century. Mihelcic et al. (2003) described sustainable manufacturing as "the design of human and industrial systems to ensure that humankind's use of natural resources and cycles do not lead to diminished quality of life due either to losses in future economic opportunities or to adverse impacts on social conditions, human health, and the environment." Later, Allwood et al. (2008) defined green manufacturing as "developing technologies to transform materials without emission of greenhouse gases, use of non-renewable or toxic materials, or generation of waste." On the other hand, the United States Department of Commerce (2010) explained sustainable manufacturing as "the creation of manufacturing products that use materials and processes that minimize negative environmental impacts, conserve energy and natural resources, are safe for employees, communities, and consumers and are economically sound." Overall, the essence of sustainable manufacturing appears to be process configuration to generate high-value products by revamping the production system with higher outputs, green technology support, and economies of scale (Lee et al., 2017). To be sustainable, it is crucial to keep absorptive and regenerative capacities well above waste generation and resource extraction rates. However, environmental issues, such as global warming and ozone depletion, clearly demonstrate that waste generation rates and energy resource extraction rates are exceeding the world's natural capacity to regenerate and consume (Mohd Helmi et al., 2019).

Therefore, to achieve the status of a developed nation, it is important for Malaysian firms to improve their sustainable development process. Despite various types of assistance provided by the authorities to stimulate sustainable production, the implementation of sustainable manufacturing by Malaysian firms is still ambiguous. A study conducted among 36 manufacturing firms from various sectors supported previous findings that the adaptation of sustainable practices remains limited to the "6R approach", namely, "reduce, reuse, recycle, recover, redesign, and remanufacture" (Hami et al., 2019). Meanwhile, research on 150 Malaysian manufacturers discovered that while the application of internally-focused SMPs is substantial, the implementation of externally-focused SMPs is only average, indicating that firms are unprepared to thoroughly consolidate sustainability requirements and guidelines when dealing with the expectations of external stakeholders, namely consumers, suppliers, and societies (Shakeel et al., 2019). Thus, manufacturers should now take aggressive actions by incorporating sustainability concepts into their strategic actions not just to attain better financial achievement, but also to safeguard the environment and improve social welfare.

\subsection{Firm Capabilities, Sustainable Manufacturing Practices, and Sustainability Performance}

Environmental issues have led consumers to demand to "green their own supply chain" and urge upstream firms to provide green and biodegradable products. Stakeholders' growing expectations pertaining social issues have also pushed firms to pay attention to corporate social responsibility, a healthy corporate image, and social compliance to avoid 
dissatisfaction and public protests. Moreover, to adopt a sustainable action plan, firms have been encouraged to change their attitudes, cultures, and interests to address the human aspect of sustainable management (Renwick et al., 2016). Jabbour (2015) concluded that many firms are converting to the green phase on account of consumer demands, green consumerism, and sustainability requirements.

Previous studies have demonstrated mixed results between firm capabilities and firm performance. Some researchers revealed a direct relationship, while others highlighted that this link is mediated and moderated by other variables (Graham \& McAdam, 2016). Given this inconsistency, strategic action could fill the gap between capabilities and performance. Firm capabilities must be integrated with adequate strategic actions to be competent (Shuen et al., 2014), as strategic actions outline the activities required by firms to realize the value of their capabilities. Strategic action thus defines "what the firm does" while capabilities define "how well the firm does it". Strategic actions also complement firm capabilities by capitalizing on them and aiding the implementation of initiatives. Therefore, a research framework that considers the mediating effect of strategic actions between firm capabilities and sustainability performance would provide insight into how valuable capabilities can be utilized to positively contribute to sustainability performance (Kauppila, 2015).

In this paper, we posit SMPs as an important strategic action applied by manufacturing firms to preserve the environment and improve the quality of human life through their activities (Salwa et al., 2017). SMPs refer to "the ability to use natural resources in manufacturing intelligently to fulfil economic, environmental, and social aspects and thus, preserve the environment and improve the quality of life" (Garetti \& Taisch, 2012). It is thus crucial for firms to incorporate the environmental, economic, and social aspects of sustainability into their daily operations to improve sustainability performance. For example, Das (2018) examined the relationship between environmental management practices and firm operational performance in the Indian manufacturing industry, finding that environmental management practices lead to competitiveness and firm performance when mediated by environmental performance. Schrettle et al. (2014) mentioned that "firms that have already obtained a track record in sustainability by gaining experience and important capabilities in sustainability management are better positioned to engage in further sustainability initiatives." In the same study, they recognized that new technologies which include sustainability efforts facilitate SMPs and the development of green products. Therefore, with increasing competition, SMPs should be acknowledged as a strategic action that improves productivity, green image, and quality status, thereby granting a greater competitive edge and performance in the market.

In the past, numerous studies have attempted to prove that sustainability is a capability that allows firms to adapt and alter themselves in different situations to achieve sustainability performance (Leonidou et al., 2015). A new sustainability model should integrate sustainability into firms' core strategy to create significant social and environmental value on top of economic returns. Such a model would address current issues and provide solutions that embed environmental and social considerations for a better and brighter future. This is 
because within the sustainability context, economic value creation cannot be taken as the sole contributor to firm performance. The effect of manufacturing activities on environmental and social aspects is also incorporated into the evaluation of firm performance, which is called sustainability performance (Salwa et al., 2017). Sustainability performance represents a firm's ability to acquire an everlasting competitive edge in financial returns by taking into account the effects of operational activities on the ecological and societal system while concurrently fulfilling stakeholders' requirements (Paulraj, 2011).

Consequently, a new development strategy should encompass political, economic, social, technological, and environmental dimensions. To shift into this new paradigm, McCormick et al. (2016) urged that a thorough and thoughtful change is required not only in firms' present production systems, but also in their ways of managing issues related to society and the consumption of natural resources essential to human life.

In this paper, sustainability performance refers to the economic, environmental, and social performance of manufacturing SMEs. Economic performance specifies firms' growth in sales and profit relative to competitors, increase in market share, return on investment, and return on sales. Environmental performance is signified by a reduction in waste discharged to the environment, a decrease in the consumption of hazardous materials, a decline in energy consumption, compliance with environmental regulations, and a decrease in the frequency of environmental accidents. Social performance indicates the ability of firms to improve overall stakeholder welfare and community health and safety, reduce environmental impacts on the general public, and improve awareness and protection of human rights in the community served (Mohd Helmi et al., 2019).

According to Beske et al. (2014), the application of dynamic capabilities for sustainable supply chain management is able to improve sustainability performance along the supply chain. This is because dynamic capabilities allow firms to explore the opportunities available in the business environment and actively establish their supply chains in sustainable manners. From an alternative viewpoint, sustainability can be built when firms develop innovative strategies that engage society members in defining environmental and social value. In the sustainability literature, process innovation is created when lean and environmental practices are combined (Fercoq et al., 2016). Process innovation, in turn, helps firms improve sustainability performance by minimizing raw material inputs and maximizing productivity (Piercy \& Rich, 2015). Huo (2019) further showed that green practices and lean manufacturing perform various roles in accomplishing sustainability performance. From a customer point of view, lean manufacturing is the main enabler of superior sustainability performance, as it positively impacts social, environmental, and economic performance. From a supplier standpoint, green initiatives play a key role in bringing firms to a higher level of sustainability performance by facilitating societal and economic performance. Despite these previous studies, detailed research on dynamic capabilities for sustainability performance is inadequate in the literature. There is a need for future research to assess the link between dynamic capabilities and sustainability in-depth so firms can establish required 
practices and modify their strategies to face sustainability issues (Leonidou et al., 2015). In addition, limited studies have examined triple bottom line dimensions when evaluating the effect of sustainable development on manufacturing firms' sustainability performance. Moving forward, scholars should look into the directions and action plans for firms to implement innovative technologies and environmental strategies in favor of achieving greater sustainability performance (Kuo \& Smith, 2018).

\section{Conceptual Framework and Rationale}

To empirically verify our research questions, our proposed research methodology process is depicted in Figure 5. First, we conducted an extensive literature search to explore current sustainability concepts and research issues. We then narrowed our scope to issues encountered by Malaysian manufacturing SMEs. The most commonly used terminologies of sustainable practices and capabilities were subsequently identified and compared. Based on this, we proposed an explanatory quantitative study to comprehend the link between firm capabilities and multidimensional sustainability performance with the integration of SMPs. Following the quantitative approach, questionnaires should be designed with valid instruments and distributed to target respondents from Malaysian manufacturing SMEs who have experience and knowledge in sustainable practices. Content validity and reliability of the questionnaire should be assessed as well before data analysis is performed. The results of the analysis would establish the link between firm capabilities, SMPs, and sustainability performance, thereby providing useful recommendations for the manufacturing sector and directions for future studies.

\begin{tabular}{|c|}
\hline Conduct extensive literature review to identify current sustainability issues \\
\hline Identify key sustainability issues, practices, and capabilities in manufacturing SMEs \\
\hline Compare and contrast sustainable practices and capabilities \\
\hline Design questionnaire with valid instruments \\
\hline$\checkmark$ \\
\hline Collect primary data through distribution of questionnaires \\
\hline$\checkmark$ \\
\hline sustainability performance data to identify the relationship between firm capabilities, SMPs, and \\
\hline \\
\hline Offer suggestions for future studies and recommendations for manufacturing SMEs \\
\hline
\end{tabular}

Figure 5. Proposed research methodology 


\section{Macrothink}

Scholars have adopted and applied different sustainable concepts and terminologies in the past literature. The term 'eco' has been used interchangeably with the term 'green'. Both carry a similar meaning as 'ecological', 'environmental', 'green', 'lean', 'natural', and 'sustainable'. Accordingly, despite their various names, most sustainable practices and capabilities are interrelated, with the overall intention of minimizing environmental and social impacts. Table 1 presents 26 key sustainable practices and capabilities extracted from 32 research articles in the last decade, whose respective authors are shown in Table 2.

Table 1. Sustainable practices and capabilities extracted from articles

\begin{tabular}{|c|c|c|c|}
\hline No. & Sustainable practices and capabilities & No. & Sustainable practices and capabilities \\
\hline 1 & Green production innovation & 14 & Green practices \\
\hline 2 & $\begin{array}{l}\text { Green approaches and sustainable } \\
\text { initiatives }\end{array}$ & 15 & Lean manufacturing process \\
\hline 3 & Sustainable manufacturing process & 16 & $\begin{array}{l}\text { Green supply chain management } \\
\text { practices }\end{array}$ \\
\hline 4 & $\begin{array}{l}\text { Environment-friendly purchase and } \\
\text { sustainable packaging }\end{array}$ & 17 & $\begin{array}{l}\text { Environmental orientation and resource } \\
\text { commitment }\end{array}$ \\
\hline 5 & $\begin{array}{l}\text { Environmental, technological, cultural, } \\
\text { and risk management practices }\end{array}$ & 18 & Innovative capabilities \\
\hline 6 & $\begin{array}{l}\text { Sustainability-oriented } \\
\text { capabilities }\end{array}$ & 19 & Sustainable capabilities \\
\hline 7 & $\begin{array}{ll}\text { Natural } & \text { resource-based } \\
\text { capabilities } & \end{array}$ & 20 & Eco innovation culture \\
\hline 8 & $\begin{array}{l}\text { Supplier environmental management } \\
\text { capabilities }\end{array}$ & 21 & Environmental management practices \\
\hline 9 & $\begin{array}{l}\text { Green management and mass } \\
\text { customization }\end{array}$ & 22 & Manufacturing technology \\
\hline 10 & Innovation process & 23 & $\begin{array}{l}\text { Pollution prevention, product } \\
\text { stewardship, process stewardship, clean } \\
\text { technology }\end{array}$ \\
\hline 11 & Environmental management system & 24 & $\begin{array}{l}\text { Firm environmental management } \\
\text { capabilities }\end{array}$ \\
\hline 12 & Eco capabilities & 25 & $\begin{array}{l}\text { Sustainable supply chain management } \\
\text { practices }\end{array}$ \\
\hline 13 & Green innovation adoption & 26 & Green sustainable product development \\
\hline
\end{tabular}


Table 2. Sustainable practices and capabilities by respective authors

\begin{tabular}{|c|c|c|c|c|c|c|c|c|c|c|c|c|c|c|c|c|c|c|c|c|c|c|c|c|c|c|}
\hline \multirow{2}{*}{ Articles } & & \multirow{2}{*}{2} & \multirow{2}{*}{3} & \multirow{2}{*}{4} & \multirow{2}{*}{5} & \multirow{2}{*}{6} & \multirow{2}{*}{7} & \multirow{2}{*}{8} & \multirow{2}{*}{9} & \multirow{2}{*}{$\begin{array}{l}1 \\
0\end{array}$} & \multirow{2}{*}{$\begin{array}{l}1 \\
1 \\
\end{array}$} & \multirow{2}{*}{$\begin{array}{l}1 \\
2\end{array}$} & \multirow{2}{*}{$\begin{array}{l}1 \\
3\end{array}$} & \multirow{2}{*}{$\begin{array}{l}1 \\
4 \\
\end{array}$} & $\begin{array}{l}1 \\
5 \\
\end{array}$ & & 1 & 1 & & & & & & & & \\
\hline & & & & & & & & & & & & & & & $\begin{array}{l}1 \\
5 \\
\end{array}$ & & 7 & 8 & 9 & 0 & 1 & 2 & 3 & 4 & 5 & 6 \\
\hline Zailani et al. (2012) & $\mathrm{X}$ & - & - & $\mathrm{X}$ & - & - & - & - & - & - & - & - & - & - & - & - & - & - & - & - & - & - & 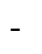 & & & - \\
\hline Ramayah et al. (2013) & - & $\mathrm{X}$ & - & - & - & - & - & - & - & - & - & - & - & - & - & - & - & - & - & - & - & - & - & - & 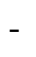 & - \\
\hline Tontiset (2015) & - & - & $\mathrm{X}$ & - & - & - & - & - & - & - & - & - & - & - & - & - & - & - & - & - & - & - & - & 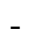 & 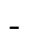 & - \\
\hline Norazlan (2014) & - & - & - & - & $\mathrm{X}$ & - & - & - & - & - & - & - & - & - & - & - & - & - & - & - & - & - & - & 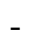 & 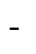 & - \\
\hline Iles and Martin (2013) & - & - & - & - & - & $X$ & - & - & - & - & - & - & - & - & - & - & - & - & - & - & - & - & - & - & - & - \\
\hline Kumar et al. (2017) & - & - & - & - & - & - & $\mathrm{X}$ & - & - & - & - & - & - & - & - & - & - & - & - & - & - & - & - & - & - & - \\
\hline Wong et al. (2012) & - & - & - & - & - & - & - & $X$ & - & - & - & - & - & - & - & - & - & - & - & - & - & - & - & - & - & - \\
\hline Trentin et al. (2015) & - & - & - & - & - & - & - & - & $\mathrm{X}$ & - & - & - & - & - & - & - & - & - & - & - & - & - & - & - & - & - \\
\hline Zhang and Yang (2016) & - & - & - & - & - & - & - & - & - & $X$ & - & - & - & - & - & - & - & - & - & - & - & - & - & - & - & - \\
\hline Huo et al. (2019) & - & - & - & - & - & - & - & - & - & - & - & - & - & $\mathrm{X}$ & - & - & - & - & - & - & - & - & - & - & - & - \\
\hline Henao et al. (2018) & - & - & - & - & - & - & - & - & - & - & - & - & - & - & $\mathrm{X}$ & - & - & - & - & - & - & 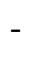 & - & 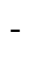 & 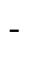 & - \\
\hline Vijayvargy (2017) & - & - & - & - & - & - & - & - & - & - & - & - & - & - & - & $\mathrm{X}$ & - & - & - & - & - & - & - & - & - & - \\
\hline Zhang and Sara (2015) & - & - & - & - & - & - & - & - & - & - & - & - & - & - & - & - & $\mathrm{X}$ & - & - & - & - & - & - & - & - & - \\
\hline $\begin{array}{l}\text { Bhupendra and Sangle } \\
\text { (2015) }\end{array}$ & - & - & - & - & - & - & - & - & - & - & - & - & - & - & - & - & - & $\mathrm{X}$ & - & - & - & - & - & - & - & - \\
\hline Aboelmaged & - & - & - & - & - & - & - & - & - & - & - & - & $\mathrm{X}$ & - & - & - & - & - & $\mathrm{X}$ & - & - & - & - & - & - & - \\
\hline Hashem (2019) & & & & & & & & & & & & & & & & & & & & & & & & & & \\
\hline Schrettle et al. (2014) & - & - & - & - & - & - & - & - & - & - & - & - & - & - & - & - & - & - & - & - & - & $\mathrm{X}$ & & 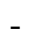 & - & - \\
\hline Maryam et al. (2015) & - & - & - & - & - & - & - & - & - & - & - & - & - & - & - & - & - & - & - & - & - & - & $\mathrm{X}$ & - & - & - \\
\hline Rashid et al. (2015) & - & - & - & - & - & - & - & - & - & - & $\mathrm{X}$ & - & - & - & - & - & - & - & - & $\mathrm{X}$ & - & - & - & - & - & - \\
\hline Liang and Liu (2016) & - & - & - & - & - & - & - & - & - & - & - & - & - & - & - & - & - & - & - & - & - & - & - & $\mathrm{X}$ & - & - \\
\hline $\begin{array}{l}\text { Roxas and Chadee } \\
(2016)\end{array}$ & - & - & - & - & - & - & - & - & - & - & - & - & - & - & - & - & - & $\mathrm{X}$ & - & - & $\mathrm{X}$ & - & - & - & - & - \\
\hline Das (2018) & - & - & - & - & - & - & - & - & - & - & - & - & - & - & - & - & - & - & - & - & - & - & - & - & $\mathrm{X}$ & \\
\hline Kuo and Smith (2018) & - & - & - & - & - & - & - & - & - & - & - & - & - & - & - & - & - & - & - & - & - & - & - & - & - & $X$ \\
\hline Gabler et al. (2015) & - & - & - & - & - & - & - & - & - & - & - & $\mathrm{X}$ & - & - & - & - & - & - & - & - & - & - & - & - & - & - \\
\hline Beske et al. (2014) & - & - & - & - & - & $\mathrm{X}$ & & - & - & - & - & - & - & - & - & - & - & - & - & - & - & - & - & - & - & - \\
\hline Dangelico et al. (2016) & - & - & - & - & - & $X$ & & - & - & - & - & - & - & - & - & - & - & - & - & - & - & - & - & - & - & - \\
\hline Roscoe et al. (2015) & - & - & - & - & - & - & $X$ & - & - & - & - & - & - & - & - & - & - & - & - & - & - & - & - & - & - & - \\
\hline Masoumik (2015) & - & - & - & - & - & - & $X$ & - & - & - & - & - & - & - & - & - & - & - & - & - & - & - & - & - & - & - \\
\hline $\begin{array}{l}\text { Graham and McAdam } \\
\text { (2016) }\end{array}$ & - & - & - & - & - & - & $X$ & - & - & - & - & - & - & - & - & - & - & - & - & - & - & - & - & - & - & - \\
\hline Zaid et al. (2018) & - & - & - & - & - & - & - & - & - & - & - & - & - & - & - & $\mathrm{X}$ & - & - & - & - & - & - & - & - & - & - \\
\hline Lidija and Robert (2014) & - & - & - & - & - & - & - & - & - & - & - & - & - & - & - & - & - & $\mathrm{X}$ & - & - & - & - & - & - & - & - \\
\hline Giniunienea & - & - & - & - & - & - & - & - & - & - & - & - & - & - & - & - & - & $X$ & - & - & - & - & - & - & - & - \\
\hline urksiene (2015) & & & & & & & & & & & & & & & & & & & & & & & & & & \\
\hline
\end{tabular}

Note. $\mathrm{X}$ denotes key sustainable practices and capabilities highlighted by authors in their 
respective article.

In the past, research on sustainable concepts and practices mostly revolved around improvement in economic and environmental aspects. The main areas of focus were business risk, waste generation, material and energy efficiency, environmentally friendly products and services, green manufacturing, environmental pollution, and consumption of raw materials (Habidin et al., 2015). In comparison, current studies on SMPs have evolved as an adaptation to the changing business environment. Emphasis is now given to the pursuit of better operational and business performance without neglecting environmental and social wellbeing. Indeed, numerous sustainable practices covering environment, social, and economic dimensions have been found in the manufacturing industry, namely cleaner production, eco-efficiency, employee relations, supplier relations, customer relations, community relations, closed-loop production, and industrial relations (Hami et al., 2019).

Recent studies have demonstrated that SMEs' financial and operational challenges have led to limited financial resources and operational disruptions (Che Omar, 2020). Manufacturing SMEs thus tend to prioritize financial returns rather than cleaner technologies or sustainable operations. Accordingly, the implementation of SMPs in SMEs is limited to "3R" activities under close-loop production. These firms also neither proactively involve in activities to improve corporate social responsibility nor take efforts to collaborate with neighborhood organizations to improve industrial relations. Unsurprisingly, earlier studies have reported that sustainable strategies in the Malaysian manufacturing industry are mostly productionand process-oriented, neglecting the importance of the product life cycle and sustainable end-of-life management (Salwa et al., 2017).

On the basis of research evidence suggesting that SMPs can contribute to manufacturers' economic, environmental, and social performance, this paper complements previous studies by looking into different aspects of SMPs that can improve the sustainable performance of manufacturing SMEs, for example, continuous product improvement approaches and end-of-life system optimization. The essence of this paper targets the dimensions of the sustainable manufacturing process, sustainable production design and development, sustainable supply chain management, and sustainable end-of-life management. These strategies create value for manufacturing SMEs by developing opportunities and mitigating risks related to sustainability. By outlining the required activities in detail, SMPs complement firm capabilities by capitalizing on them and aiding the implementation of initiatives. Therefore, our proposed research framework, illustrated in Figure 6, considers the mediating effect of SMPs as a dynamic strategic action internal to firms that transforms firm capabilities into sustainability performance. 


\begin{tabular}{|c|c|c|}
\hline \multirow{3}{*}{ Firm Capabilities } & $\begin{array}{c}\text { Sustainable } \\
\text { Manufacturing Practices }\end{array}$ & $\begin{array}{l}\text { Sustainability } \\
\text { Performance }\end{array}$ \\
\hline & Sustainable Manufacturing Process & Environmental \\
\hline & $\begin{array}{l}\text { Sustainable Product Design \& Development } \\
\text { Sustainable Supply Chain Management } \\
\text { Sustainable End of Life Management }\end{array}$ & $\begin{array}{c}\text { Social } \\
\text { Economic }\end{array}$ \\
\hline
\end{tabular}

Figure 6. Proposed research framework

\section{Final Thoughts and Conclusion}

The objective of this paper was to establish SMPs as a dynamic internal strategic action of manufacturing SMEs that transforms firm capabilities into sustainability performance. In summary, environmental and health issues have arisen in Malaysia as a result of the poor implementation of its sustainable management systems and the inability of its current waste management system to handle substantial municipal solid waste disposals (Chua \& Bashir, 2019). The Covid-19 outbreak further dampened sustainable development in Malaysia and brought devastating effects to firms' economic, environmental, and social performance. We hereby call for more research on SMPs in relation to the sustainability performance of Malaysian manufacturing SMEs. Sustainable practices and capabilities have been identified as significant factors across multiple academic works in developed and developing countries (Salwa et al., 2017). As previous studies exhibited mixed results on the firm capabilities-firm performance link, we put forth a strong rationale for research on SMPs as a mediating strategic action that fills this gap by explaining the relationship between firm capabilities and sustainability performance. Further research that provides insight on the different dimensions of SMPs is essential to ascertain how SMPs function as strategic actions to effectively support firms' achievement of sustainability performance.

This paper enriched the Dynamic Capability View by applying the sustainability model to explain the development of sustainability performance among Malaysian manufacturing SMEs. We also integrated the relevant variables into one framework to achieve triple bottom line sustainability performance, i.e. environmental, social, and economic performance. This article thus informs firms and authorities on the importance of SMPs for superior performance, in addition to guiding firms towards understanding and improving their current SMPs. At the firm level, manufacturing SMEs can conduct sustainability assessments to evaluate their current SMPs and select suitable ones to be adapted for better sustainability performance. Managers from the sector can also introduce effective sustainable strategies for their firms' operation management to improve sustainability-related outcomes. At the governmental level, policy makers can promote effective SMPs by providing various aids in the form of strategic planning, governance, facilities, financing, and technology to support manufacturing SMEs. With these efforts, SMPs can increase the competitiveness of the 


\section{1) Macrothink}

Malaysian manufacturing sector and pave the way for Malaysia to become a developed nation.

\section{Acknowledgments}

I would like to express my gratitude to Associate Professor Dr Devika Nadarajah for her immense knowledge, patience, and motivation throughout the process of writing this paper. My sincere appreciation also goes to Professor Dr Sazali Abd Wahab for sharing his pearls of wisdom and comments, which greatly improved the manuscript.

\section{References}

Aboelmaged, M., \& Hashem, G. (2019). Absorptive capacity and green innovation adoption in SMEs: The mediating effects of sustainable organisational capabilities. Journal of Cleaner Production, 220(2), 853-863. https://doi.org/10.1016/j.jclepro.2019.02.150

Allwood, J. M., Laursen, S. E., Russell, S. N., de Rodríguez, C. M., \& Bocken, N. M. P. (2008). An approach to scenario analysis of the sustainability of an industrial sector applied to clothing and textiles in the UK. Journal of Cleaner Production, 16(12), 1234-1246. https://doi.org/10.1016/j.jclepro.2007.06.014

Bank Negara Malaysia. (2020). Economic and financial data for Malaysia. Retrieved from https://www.bnm.gov.my/index.php?ch=statistic_nsdp

Bank Negara Malaysia. (2020). Financial stability review second half 2019. Retrieved from https://www.bnm.gov.my/ar2019/

Beske, P., Land, A., \& Seuring, S. (2014). Sustainable supply chain management practices and dynamic capabilities in the food industry: A critical analysis of the literature. International Journal of Production Economics, 152, 131-143. https://doi.org/10.1016/j.ijpe.2013.12.026

Bhupendra, K. V., \& Sangle, S. (2015). What drives successful implementation of pollution prevention and cleaner technology strategy? The role of innovative capability. Journal of Environmental Management, 155, 184-192. https://doi.org/10.1016/j.jenvman.2015.03.032

Cai, W., \& Zhou, X. (2014). On the drivers of eco-innovation: Empirical evidence from China. Journal of Cleaner Production, 79(5), 239-248. https://doi.org/10.1016/j.jclepro.2014.05.035

Chakrabarty, S., \& Wang, L. (2012). The long-term sustenance of sustainability practices in MNCs: A dynamic capabilities perspective of the role of $R \& D$ and internationalization. Journal of Business Ethics, 110(2), 205-217. https://doi.org/10.1007/s10551-012-1422-3

Che Omar, A. R., Ishak, S., \& Jusoh, M. A. (2020). The impact of Covid-19 movement control order on SMEs' businesses and survival strategies. Malaysian Journal of Society and Space, 16(2), 139-150. https://doi.org/10.17576/geo-2020-1602-11 
Chua, H. S., \& Bashir, M. J. K. (2019). A sustainable pyrolysis technology for the treatment of municipal solid waste in Malaysia. AIP Conference Proceedings, 2124(1), 020016. https://doi.org/10.1063/1.5117076

Dangelico, R. M., Pujari, D., \& Pontrandolfo, P. (2016). Green product innovation in manufacturing firms: A sustainability-oriented dynamic capability perspective. Business Strategy and the Environment, 26, 490 - 506. https://doi.org/10.1002/bse.1932

Das, D. (2018). The impact of sustainable supply chain management practices on firm performance: Lessons from Indian organizations. Journal of Cleaner Production, 203, 179-196. https://doi.org/10.1016/j.jclepro.2018.08.250

Department of Statistics Malaysia. (2020). Report of special survey on effects of Covid-19 on economy and individual (Round 1). Retrieved from https://www.dosm.gov.my/

Elkington, J. (1997). Cannibals with forks: The triple bottom line of 21st century business. New Society Publishers. https://doi.org/10.1002/tqem.3310080106

Fercoq, A., Lamouri, S., \& Carbone, V. (2016). Lean/Green integration focused on waste reduction techniques. Journal of Cleaner Production, 137, 567-578. https://doi.org/10.1016/j.jclepro.2016.07.107

Gabler, C. B., Richey, R. G., \& Jr, Rapp, A. (2015). Developing an eco-capability through environmental orientation and organizational innovativeness. Industrial Marketing Management, 45(1), 151-161. https://doi.org/10.1016/j.indmarman.2015.02.014

Garetti, M., \& Taisch, M. (2012). Sustainable manufacturing: Trends and research challenges. Production Planning and Control, 83-104. https://doi.org/10.1080/09537287.2011.591619

Giniuniene, J., \& Jurksiene, L. (2015). Dynamic capabilities, innovation and organizational learning: Interrelations and impact on firm performance. Social and Behavioral Sciences, 213, 985-991. https://doi.org/10.1016/j.sbspro.2015.11.515

Graham, S., \& McAdam, R. (2016). The effects of pollution prevention on performance. International Journal of Operations and Production Management, 36(10), 1333-1358. https://doi.org/10.1108/IJOPM-05-2015-0289

Habidin, N. F., Mohd Zubir, A. F., Mohd Fuzi, N., Mohd Latip, N. A., \& Azhari, A. M. N. (2015). Sustainable manufacturing practices in Malaysian automotive industry: Confirmatory factor analysis. Journal of Global Entrepreneurship Research, 5, 14. https://doi.org/ 10.1186/s40497-015-0033-8

Hahn, T., Pinkse, J., Preuss, L., \& Figge, F. (2015). Tensions in corporate sustainability: Towards an integrative framework. Journal of Business Ethics, 127(2), 297-316. https://doi.org/10.1007/s10551-014-2047-5

Hami, N., Yamin, F. M., Shafie, S. M., \& Muhamad, M. R. (2019). An analysis of sustainable 
manufacturing practices in Malaysian SMEs. International Journal of Recent Technology and Engineering, 8, 2277-3878. https://doi.org/10.14716/ijtech.v9i8.2751

Henao, R., Sarache, W., \& Gomez, I. (2019). Lean manufacturing and sustainable performance: Trends and future challenges. Journal of Cleaner Production, 208, 99-116. https://doi.org/10.1016/j.jclepro.2018.10.116

Huo, B., Gu, M., \& Wang, Z. (2019). Green or lean? A supply chain approach to sustainable performance. Journal of Cleaner Production, 216, 152-166. https://doi.org/10.1016/j.jclepro.2019.01.141

Iles, A., \& Martin, A. N. (2013). Expanding bioplastics production: Sustainable business innovation in the chemical industry. Journal of Cleaner Production, 45, 38-49. https://doi.org/10.1016/j.jclepro.2012.05.008

Iranmanesh, M., Jayaraman, K., Imrie, B. C., \& Zailani, S. (2016). Promoting products through volume discount: Evidence from Malaysia. Journal of Promotion Management, 22, 71-88. https://doi.org/10.1080/10496491.2015.1107009

International Labor Organization. (2020). ILO monitor: COVID-19 and the world of work. Retrieved from https://www.ilo.org/wcmsp5/groups/public/---dgreports/-dcomm/documents/briefingnote/wcms_743146.pdf

Jabbour, C. J. C. (2015). In the eye of the storm: Exploring the introduction of environmental issues in the production function in Brazillian companies. International Journal of Production Research, 48(21-22), 6315-6339. https://doi.org/10.1080/00207540802425401

Kauppila, O.-P. (2015). Alliance management capability and firm performance: Using resource-based theory to look inside the process black box. Long Range Planning, 48(3), 151-167. https://doi.org/10.1016/j.lrp.2013.08.006

Koh, S. C. L., Gunasekaran, A., \& Tseng, C. S. (2012). Cross-tier ripple and indirect effects of directives WEEE and RoHS on greening a supply chain. International Journal of Production Economics, 140(1), 305-317. https://doi.org/10.1016/j.ijpe.2011.05.008

Kumar, S. (2019, November 13). Glove makers show they care about foreign workers' welfare, enhance code of conduct. The Sun Daily. Retrieved from https://www.thesundaily.my/business/glove-makers-show-they-care-about foreign-workers-welfare-enhance-code-of-conduct-AB1605552

Kuo, T. C., \& Smith, S. (2018). A systematic review of technologies involving eco-innovation for enterprises moving towards sustainability. Journal of Cleaner Production, 192, 207-220. https://doi.org/10.1016/j.jclepro.2018.04.212

Lee, M. D., Rahmat, A. D., \& Heng, J. N. (2017). Sustainability paradigm for Malaysian manufacturing SMEs: An operations research approach. International Journal of Business and Technopreneurship, 7(3), 355-368. 
Leonidou, L. C., Leonidou, C. N., Fotiadis, T. A., \& Aykol, B. (2015). Dynamic capabilities driving an eco-based advantage and performance in global hotel chains: The moderating effect of international strategy. Tourism Management, 50(3), 268-280. https://doi.org/10.1016/j.tourman.2015.03.005

Liang, D., \& Liu, T. (2016). Does environmental management capability of Chinese industrial firms improve the contribution of corporate environmental performance to economic performance? Journal of Cleaner Production, 142, 2985-2998. https://doi.org/10.1016/j.jclepro.2016.10.169

Liboni, L. B., Jabbour, C. J. C., Jabbour, A., \& Devika, K. (2016). Sustainability as a dynamic organizational capability: A systematic review and a future agenda toward a sustainable transition. Journal of Cleaner Production, 142, 308-322. https://doi.org/10.1016/j.jclepro.2016.07.103.

Lidija, B., \& Robert, D. H. (2014). Dynamic capabilities vs. innovation capability: Are they related? Journal of Small Business and Enterprise Development, 21(3), 368-384. https://doi.org/10.1108/JSBED-02-2014-0018

Marketing Magazine Asia. (2020). Sentiment study on the impact of Covid 19 MCO on Malaysians. Retrieved from https://marketingmagazine.com.my/sentiment-study-on-the-impact-of-covid-19-mco-on-mala ysians/

Maryam, M., Zuhdi, A., Amindoust, A., Sakundarini, N., Dawal, S. Z., Tahriri, F., ... Tho, N. H. (2015). Empirical evidence of AMT practices and sustainable environmental initiatives in Malaysian automotive SMEs. International Journal of Precision Engineering and Manufacturing, 16(6), 1195-1203. https://doi.org/10.1007/s12541-015-0154-6

McCormick, K., Neij, L., Mont, O., Ryan, C., Rodhe, H., \& Orsato, R. (2016). Advancing sustainable solutions: An interdisciplinary and collaborative research agenda. Journal of Cleaner Production, 123, 1-4. https://doi.org/10.1016/j.jclepro.2016.01.038

Mihelcic, J. R., Crittenden, J. C., Small, M. J., Shonnard, D. R., Hokanson, D. R., Zhang, Q., \& Schnoor, J. L. (2003). Sustainability science and engineering: The emergence of a new metadiscipline. Environmental Science and Technology, 37(23), 5314-5324. https://doi.org/10.1021/es034605h

Mohd Helmi, A., Suhaiza, Z., Mohammad, I., \& Foroughi, B. (2019). Impacts of environmental factors on waste, energy, and resource management and sustainable performance. Sustainability, 11, 2443. https://doi.10.3390/su11082443

Norazlan, A. N. I., Habidin, N. F., Roslan, M. H., Zaini, M., \& Zainudin. (2014). The development of sustainable supply chain management practices and sustainable performance in Malaysian healthcare industry. International Journal of Ethics in Engineering and Management Education, 1(2), 51-55. https://doi.org/10.1504/IJQI.2014.066381 
Paulraj, A. (2011). Understanding the relationships between internal resources and capabilities, sustainable supply management and organizational sustainability. Journal of Supply Chain Management, 47(1), 19-37. https://doi.org/10.1111/j.1745-493X.2010.03212.x

Piercy, N., \& Rich, N. (2015). The relationship between lean operations and sustainable operations. International Journal of Operation and Production Management, 35(2), 282-315. https://doi.org/10.1108/IJOPM-03-2014-0143

Rashid, N., Jabar, J., Yahya, S., \& Shami, S. (2015). Dynamic eco innovation practices: A systematic review of state of the art and future direction for eco innovation study. Asian Social Science, 11(1), 1-14. https://doi.org/10.5539/ass.v11n1p8

Renwick, D. W., Jabbour, C. J., Muller-Camen, M., Redman, T., \& Wilkinson, A. (2016). Contemporary developments in green (environmental) HRM scholarship. The International Journal of Human Resource Management, 27(2), 114-128. https://doi.org/10.1080/09585192.2015.1105844

Roscoe, S., Cousins, P., \& Lamming, R. (2015). Developing eco-innovations: A three-stage typology of supply networks. Journal of Cleaner Production, 112(3), 1948-1959. https://doi.org/10.1016/j.jclepro.2015.06.125

Roxas, B. \& Chadee, D. (2016). Knowledge management view of environmental sustainability in manufacturing SMEs in the Philippines. Knowledge Management Research and Practice, 14(4), 514-524. https://doi.org/10.1057/kmrp.2015.30

Salwa, H. A., Novita, S., Raja, A. R. G., \& Ramayah T. (2017). The impact of sustainable manufacturing practices on sustainability performance: Empirical evidence from Malaysia. International Journal of Operations and Production Management, 37(2), 182-204. https://doi.org/10.1108/IJOPM-04-2015-0223

Schrettle, S., Hinz, A., Rathje, M. S., \& Friedli, T. (2014). Turning sustainability into action: Explaining firms' sustainability efforts and their impact on firm performance. International Journal of Production Economics, 147, 73-84. https://doi.10.1016/j.ijpe.2013.02.030

Shakeel, P. M., Tolba, A., Al-Makhadmeh, Zafer Al-Makhadmeh, \& Mustafa, M. J. (2019). Automatic detection of lung cancer from biomedical data set using discrete AdaBoost optimized ensemble learning generalized neural networks. Neural Computing and Applications, 1-14. https://doi.org/10.1007/s00521-018-03972-2

Shehzad, A., Bashir, M. J. K., Sethupathi, S., \& Lim, J. W. (2015). An overview of heavily polluted landfill leachate treatment using food waste as an alternative and renewable source of activated carbon. Process Safety and Environmental Protection, 98, 309-318. https://doi.org/10.1016/j.psep.2015.09.005

Shuen, A., Feiler, P. F., \& Teece, D. J. (2014). Dynamic capabilities in the upstream oil and gas sector: Managing next generation competition. Energy Strategy Reviews, 3, 5-13. https://doi.org/10.1016/j.esr.2014.05.002 
SMECorp. (2019). SME annual report 2018/19. Retrieved from http://www.smecorp.gov.my/ index.php/en/resources.

Surendran, S. (2020, December 7). Covid-19 cuts Top Glove both ways. The Edge Malaysia. Retrieved from https://www.theedgemarkets.com/article/covid19-cuts-top-glove-both-ways

Svatošová, V. (2019). Identification of financial strategy in small and medium-sized entrepreneurship. ACTA Universitasis Agriculturae ET Silviculturae Mendelianae Brunensis, 65(4), 1435-1453. https://doi.org/10.11118/actaun201765041435

Syed, H. A. (2019). Sustainability in crisis: Towards business continuity in small and medium enterprises. In: Proceedings of the 17th European Conference on Computer-Supported Cooperative Work: The International Venue on Practice-centred Computing and the Design of Cooperation Technologies. Doctoral Colloquium Papers, Reports of the European Society for Socially Embedded Technologies (ISSN 2510-2591). Retrieved from https://doi.10.18420/ecscw2019_dc10.

The Star. (2020, December 1). Malaysia to charge Top Glove over worker accommodations, government says. Retrieved from https://www.thestar.com.my/business/business-news/2020/12/01/malaysia

The United Nations. (2020). Sustainable development goals. Retrieved from https://www.un.org/sustainabledevelopment/poverty/

The United Nations. (2020). Sustainable development goals. Retrieved from https://unstats.un.org/sdgs/report/2019/goal-10/

The United Nations. (2020). The sustainable development goals report 2020. Retrieved from https://unstats.un.org/sdgs/report/2020/

The United Nations. (2020). Sustainable development goals. Retrieved from https://www.un.org/sustainabledevelopment/climate-change/

Tontiset, N. (2015). The impact of institutional theory and resource-based view perspectives on environmental management system and firm performance. European Journal of Management, 15(1), 1555-4015.

U.S. Department of Commerce. (2010). Sustainable Manufacturing Initiative (SMI) and public-private dialogue. Retrieved from https://trade.gov/competitiveness/sustainablemanufacturing/docs/2010_Next_Steps.pdf

Wong, C. W. Y., Lai, K.-h., Shang, K.-C., Lu, C.-S., \& Leung, T. K. P. (2012). Green operations and the moderating role of environmental management capability of suppliers on manufacturing firm performance. International Journal of Production Economics, 140(1), 283-294. https://doi.org/10.1016/j.ijpe.2011.08.031

Zaid, A. A., Jaaron, A. A. M., \& Bon, A. T. (2018). The impact of green human resource management and green supply chain management practices on sustainable performance: An 
empirical study. Journal of Cleaner Production, 204, 965-979. https://doi.org/10.1016/j.jclepro.2018.09.062

Zailani, S., Jeyaraman, K., Vengadasan, G., \& Premkumar, R. (2012). Sustainable supply chain management (SSCM) in Malaysia: A survey. International Journal of Production Economics, 140(1), 330-340. https://doi.org/10.1016/j.ijpe.2012.02.008

Zhang, J., \& Sara. W. (2015). Eco-innovation and business performance: The moderating effects of environmental orientation and resource commitment in green-oriented SMEs: Eco-innovation and business performance. Research and Development Management, 47(5), 26-39. https://doi.org/47. 10.1111/radm.12241

Zhang, H. Y., \& Yang, F. (2016). On the drivers and performance outcomes of green practices adoption: An empirical study in China. Industrial Management and Data Systems,116(9), 2011-2034. https://doi.org/10.1108/IMDS-06-2015-0263

\section{Copyright}

Copyright for this article is retained by the author(s), with first publication rights granted to the journal.

This is an open-access article distributed under the terms and conditions of the Creative Commons Attribution license (http://creativecommons.org/licenses/by/4.0/). 